MARINADE Vol. 02(02) : 01 - 10 (Oktober 2019)

e-ISSN : 2654-4415

online : http://ojs.umrah.ac.id/index.php/marinade

\title{
PENERAPAN TEKNOLOGI PROSES PENCAMPURAN SEMI REFINED CARRAGEENAN (SRC) DAN REFINED CARRAGEENAN (RC) RUMPUT LAUT MERAH (Kappaphycus alvarezii) TERHADAP KARAKTERISTIK FISIKO-KIMIA KARAGINAN
}

\author{
Application of The Mixing Process of Semi-Refined Carrageenan (SRC) and Refined \\ Carrageenan (RC) Red Seaweed (Kappaphycus alvarezii) Against The Physicochemical \\ Characteristics of Carrageenan. \\ Aidil Fadli Ilhamdy ${ }^{1)}$, Jumsurizal ${ }^{1}$, Wan Kirana Shabilla ${ }^{\left.{ }^{*}\right)}$ \\ 1) Jurusan Teknologi Hasil Perikanan, Fakultas IImu Kelautan dan Perikanan, Universitas Maritim \\ Raja Ali
}

Korespondensi : aidilfadliilhamdy@gmail.com Diterima Juli 2019 ; Disetujui September 2019

\begin{abstract}
This study aims to determine the application of the mixing process technology of semi-refined carrageenan and refined carrageenan Kappaphycus alvarezii to the physicochemical properties of carrageenan to obtain simpler process technology but with quality products that are in accordance with carrageenan standards. Determination of the best mixing technology was carried out in several stages, refined carrageenan, and the semi-refined carrageenan and refined carrageenan mixing process technology, then followed by physico-chemical analysis, yield, moisture content, ash content, acid insoluble ash content, gel strength, viscosity, melting point, and cumulative point. The best results on carrageenan which quality standard characteristics, namely gel strength $376,46 \mathrm{~g} / \mathrm{cm} 2$, viscosity $139,47 \mathrm{CP}$, melting point $55,70{ }^{\circ} \mathrm{C}$, and the point of departure $38,00{ }^{\circ} \mathrm{C}$

Keywords: Semi-Refined Carrageenan, Refined Carrageenan, Mixing Process Technology

ABSTRAK

Penelitian ini bertujuan untuk mengetahui penerapan teknologi proses pencampuran semi refined carragenan dan refined carragenan rumput laut merah Kappaphycus alvarezii terhadap sifat fisiko-kimia karaginan untuk memperoleh teknologi proses yang lebih sederhana namun dengan kualitas produk yang sesuai dengan standar karaginan. Penentuan teknologi pencampuran terbaik dilakukan beberapa tahap yaitu pembuatan refined carrageenan dan Teknologi proses pencampuran semi refined carrageenan dan refined carrageenan. Kemudian dilanjutkan analisis fisiko-kimia yaitu rendemen, kadar air, kadar abu, kadar abu tidak larut asam, kekuatan gel, viskositas, titik leleh dan titik jendal. Hasil terbaik pada karaginan yang memiliki nilai karakteristik standar mutu karaginan yaitu kekuatan gel $376,46 \mathrm{~g} / \mathrm{cm}^{2}$, viskositas $139,47 \mathrm{cP}$, titik leleh $55,70{ }^{\circ} \mathrm{C}$, dan titik jendal $38,00^{\circ} \mathrm{C}$.
\end{abstract}

Kata kunci: Refined Carrageenan, Semi Refined Carrageenan, Teknologi Pencampuran. 


\section{PENDAHULUAN}

Industri makanan menyumbang 70$80 \%$ dari total produksi dunia, diperkirakan sekitar 45.000 metrik ton per tahun, dari yang sekitar $45 \%$ digunakan untuk produk susu dan $30 \%$ untuk daging dan daging derivative (McHugh 2003). Pemanfaatan rumput laut terus meluas pada produk non pangan seperti suplemen, industri farmasi, kosmetik, cat dan industri tekstil. Berbagai macam produk dari rumput laut dengan nilai estimasi sekitar 5-6 milyar US dolar, dan sekitar 90\% produksi digunakan untuk konsumsi pangan dunia dalam bentuk karaginan, alginat dan agar-agar (Chen et al. 2017).

Proses produksi refined carrageenan meliputi pencucian, alkalisasi, pembilasan/penyaringan, pemutihan, pemotongan, pemisahan dengan cairan alkalisasi, ekstraksi, presitipasi, pengepresan, filtrasi dan dikeringkan kembali (KEPMEN ketenagakerjaan RI 2016). Proses pemurnian bertujuan untuk menghilangkan komponen tidak larut air, yaitu selulosa, hemiselulosa, $\beta$ glucan, senyawa protein, senyawa lemak dan polimer lainnya. Salah satu penyebab warna putih kekuningan pada karaginan yaitu terdapat selulosa, pigmen fikoeritin dan fikosianin. (Wenno et al. 2012).

Berkembangnya pemanfaatan karaginan di dunia industri, mendorong perkembangan teknologi proses dalam pemanfaatan rumput laut Kappaphycus alvarezii. Beberapa industri karaginan di Filipina memproduksi karagenan dengan proses pemurnian alternatif yang lebih sederhana, dikenal sebagai karagenan PES/PNG (Kintanar et al. 1997). Setelah melakukan perebusan alkali dan pencucian air, produk dihaluskan dan dilakukan pemutihan (bleaching). Pemutihan bertujuan untuk menghilangkan warna pudar sekaligus menghilangkan bakteri. Produk Philipine natural grade (PNG) atau Processed Eucheuma Seaweed (PES) di pasar Amerika atau Eropa dikelopmpokkan sebagai bahan baku food grade.

Tujuan penelitian ini untuk mengetahui optimasi penerapan teknologi proses pencampuran semi refined carragenan dan refined carragenan terhadap sifat fisiko-kimia karaginan untuk memperoleh teknologi proses yang lebih sederhana namun dengan kualitas produk yang sesuai dengan standar karaginan.

\section{BAHAN DAN METODE}

\section{Bahan}

Bahan utama yang digunakan pada penelitian ini adalah Semi Refined Carrageenan dan Refined Carrageenan. Bahan kimia yang digunakan antara lain akuades, kalium hidroksida $(\mathrm{KOH})$ (Jerman), etanol teknis dan bahanbahan untuk uji Fisiko-kimia.

\section{Pembuatan Refined Carrageenan (RC) (Siregar et al. 2016) \\ Prosedur ekstraksi diawali dengan perendaman $30 \mathrm{~g}$ rumput laut kering}


dalam $400 \mathrm{~mL} \mathrm{KOH} \mathrm{6 \%} \mathrm{(b/v)} \mathrm{selama} 24$ jam. Selanjutnya rumput laut dipanaskan pada suhu $80^{\circ} \mathrm{C}$ selama 2 jam dalam $800 \mathrm{~mL} \mathrm{KOH} \mathrm{6 \%} \mathrm{(b/v).}$ Setelah itu rumput laut dicuci dengan air mengalir untuk proses netralisasi dan selanjutnya diekstraksi dalam $800 \mathrm{~mL}$ akuades pada suhu $80^{\circ} \mathrm{C}$ selama 2 jam. Ekstrak rumput laut diencerkan dalam akuades hangat dengan rasio 1:4 (v/v) kemudian disaring menggunakan kain nylon (100 mesh). Filtrat yang dihasilkan dipresipitasi menggunakan etanol teknis dengan rasio 1:2 (v/v). Kappa karaginan murni yang terpresipitasi dipisahkan dengan vakum filter kemudian dikeringkan dengan oven $\left(60^{\circ} \mathrm{C} ; 12\right.$ jam).

\section{Teknologi Proses Pencampuran SRC} dan RC

Pada SRC mengacu (llhamdy et al. 2019), hasil Proses SRC dan RC yang sudah dikarakterisasi sifat fisiko-kimia kemudian dilakukan pencampuran dengan berbagai perlakuan. Konsentrasi yang di campurkan antara SRC dan RC yaitu $25: 75,50: 50,75: 25$ dan 100 : 0 . Hasil Karaginan yang sudah dicampurkan kemudian di analisis kembali Kekuatan Gel, Viskositas, Titik Leleh dan Titik Jendal.

\section{Kadar Air (AOAC 2005)}

Cawan kosong yang akan digunakan dikeringkan terlebih dahulu pada suhu $105-110^{\circ} \mathrm{C}$ selama 15 menit atau samapi berat konstan, kemudian didinginkan dalam desikator selama 30 menit dan ditimbang. Sampel kira-kira sebanyak 2 gram ditimbang dan diletakkan dalam cawan kemudian dipanaskan dalam oven selama 3-4 jam pada suhu $105-110^{\circ} \mathrm{C}$. Cawan kemudian didinginkan dalam desikator dan setelah dingin ditimbang kembali.

\section{Kadar Abu (AOAC 2005)}

Prinsip analisis kadar abu adalah mengetahui jumlah abu yang terdapat pada suatu bahan terkait dengan mineral dari bahan yang dianalisis. Cawan abu porselen dibersihkan kemudian dikeringkan dalam oven bersuhu sekitar $105^{\circ} \mathrm{C}$ selama 30 menit. Cawan abu porselen yang telah dikeringkan dalam oven dimasukkan dalam desikator (30 menit) dan kemudian ditimbang (A). Sampel sebanyak $5 \mathrm{~g}(\mathrm{C})$ ditimbang kemudian dimasukkan ke dalam cawan abu porselen. Cawan abu berisi sampel dibakar diatas kompor listrik sampai tidak berasap dan dimasukkan ke dalam tanur pengabuan dimasukkan dalam desikator (30 menit) kemudian ditimbang (B).

\section{Kadar Abu Tidak Larut dalam Asam (FMC Corp 1977)}

Rumput laut yang telah diabukan dididihkan dengan $25 \mathrm{ml} \mathrm{HCl} 10 \%$ selama 5 menit. Bahan-bahan yang tidak terlarut disaring dengan menggunakan kertas saring tak berabu. Kertas saring diabukan dengan cara yang sama seperti di atas, lalu 
didinginkan dalam desikator untuk selanjutnya ditimbang.

\section{Rendemen (FMC Corp 1977)}

Rendemen

Semi

Refined

Carrageenan (SRC) sebagai hasil ekstraksi dihitung berdasarkan rasio antara berat SRC yang dihasilkan dengan berat rumput laut kering yang digunakan.

\section{Kekuatan Gel (Hayashi et al. 2007)}

Kappa karaginan murni dilarutkan dalam akuades pada konsentrasi 1,5\% kemudian ditambahkan larutan $\mathrm{KCl}$ dengan konsentrasi 0,2\%. Kekuatan gel larutan kappa karaginan murni diukur pada suhu $20^{\circ} \mathrm{C}$ menggunakan alat texture analyzer TA-XT2i.

\section{Viskositas (Siregar et al. 2016)}

Larutan 1,5\% kappa karaginan murni dipanaskan pada suhu $75^{\circ} \mathrm{C}$. Sementara itu tabung viskometer juga dimasukkan ke dalam air pada suhu $75^{\circ} \mathrm{C}$ sehingga pengukuran yang diinginkan tercapai. Selanjutnya $5 \mathrm{~mL}$ larutan kappa karaginan murni dimasukkan ke dalam tabung viskometer hingga mencapai $75 \%$ volume tabung kemudian bola viscometer dimasukkan ke dalam tabung dan dilepaskan hingga jatuh sepanjang tabung viskometer. Selang waktu tempuh bola dicatat ketika melewati dua garis Fiduciary.
Titik Leleh dan Titik Jendal (FreilePelegrin dan Robledo 1997)

Suhu pembentuk gel diperoleh dengan menambahkan $10 \mathrm{~mL}$ larutan agar panas ke dalam tabung reaksi (diameter 2,3 cm, tinggi $6 \mathrm{~cm}$ ). Manikmanik kaca (diameter $5 \mathrm{~mm}$ ) ditempatkan di tabung reaksi. Tabung dimiringkan ke atas dan ke bawah dalam bak air pada suhu kamar sampai manik-manik kaca berhenti bergerak. Suhu gel dalam tabung segera diukur dengan memperkenalkan termometer presisi (divisi $0,1{ }^{\circ} \mathrm{C}$ ). Temperatur peleburan gelin tabung reaksi (diameter $2,3 \mathrm{~cm}$, tinggi $16,5 \mathrm{~cm}$ ) diukur dengan menempatkan manik-manik besi (diameter $9 \mathrm{~mm}$ ) pada permukaan gel. Tabung reaksi dijepit dalam bak air dan suhu dinaikkan dari 50 menjadi $100{ }^{\circ} \mathrm{C}$. Titik lebur dicatat dengan termometer presisi ketika manik tenggelam ke dalam larutan.

\section{HASIL DAN PEMBAHASAN}

\section{Refined Carrageenan (RC)}

Pada proses pembuatan refined carrageenan terdapat perbedaan fisiko kimia pada refined carrageenan yang dilakukan oleh penelitian sebelumnya, ini dapat dilihat pada Tabel 1. Berdasarkan Tabel 1, Dapat dilihat bahwa rendemen pada hasil analisis adalah $16,73 \%$. Pada penelitian ini rendemen yang dihasilkan belum memenuhi standar mutu karaginan dari BSN (2009). 
Tabel 1. Fisiko Kimia Refined Carrageenan.

\begin{tabular}{|c|c|c|}
\hline \multirow{2}{*}{ Fisiko Kimia } & \multicolumn{2}{|c|}{ Refined Carrageenan } \\
\hline & Penelitian & Standar \\
\hline Rendemen (\%) & 16,73 & $\operatorname{Min} .25^{\mathrm{a}}$ \\
\hline Air (\%) & 10,09 & Maks. $12^{b}$ \\
\hline Abu (\%) & 39,71 & $15-40^{b}$ \\
\hline $\begin{array}{l}\text { Abu Tidak Larut dalam Asam } \\
(\%)\end{array}$ & 0,03 & Maks. $1^{\mathrm{b}}$ \\
\hline Kekuatan Gel $\left(\mathrm{g} / \mathrm{cm}^{2}\right)$ & 4,14 & $20-500^{b}$ \\
\hline Viskositas (cP) & 7,90 & $\operatorname{Min} .5^{\mathrm{b}}$ \\
\hline Titik Leleh $\left({ }^{0} \mathrm{C}\right)$ & $-a^{a}$ & - \\
\hline Titik Jendal $\left({ }^{0} \mathrm{C}\right)$ & $-a^{a}$ & - \\
\hline
\end{tabular}

Adapun beberapa faktor yang diduga mempengaruhi rendemen pada refined carrageenan yaitu lebih banyak dipengaruhi oleh suhu dan waktu ekstraksi pada proses semi refined carrageenan (Basmal et al. 2009). Rendemen pada suatu proses pembuatan karaginan dapat mengukur parameter efesiensi yang dapat menilai baik atau buruknya suatu proses ekstraksi pada karaginan (Siregar et al. 2016).

Menurut Hidayat (2004) Semakin baik kualitas karaginan tersebut maka karagenan tersebut memiliki kadar air yang rendah. Kadar air menunjukan bahwa sangat berpengaruh untuk mengetahui suatu kualitas pada refined carrageenan tersebut. Berdasarkan hasil analisis tersebut, kadar air pada karaginan adalah 10,09\%. Pada penelitan menunjukan bahwa kadar air ini memenuhi standar mutu karaginan yang telah ditetapkan oleh FAO (2007).
Menurut Wenno et al. (2012) Kandungan air pada karaginan dapat mempengaruhi daya simpannya. Kadar air yang rendah memiliki pengendapan yang baik dengan menggunakan etanol maupun isopropil, hal ini disebabkan karena adanya pengendap mengakibatkan serat yang ada di karaginan lebih banyak membentuk gel, sehingga kadar air dalam karaginan menjadi berkurang (Yasita dan Rachmawati 2009)

Berdasarkan hasil dari analisis, kadar abu pada karaginan adalah $39,71 \%$. Pada penelitan menunjukan bahwa kadar abu ini memenuhi standar mutu karaginan yang telah ditetapkan oleh FAO (2007). Perbedaan kadar abu masih diduga ada terdapatnya garam dan mineral pada proses pembuatan karaginan, sehingga dapat mempengaruhi kadar abu tersebut (Yuniati 2011). Selain itu, Menurut Harun et al. (2013) menyatakan bahwa 
kadar abu dipengaruhi oleh banyaknya kandungan mineral di lokasi pembudidayaan rumput laut dan tinggi rendahnya salinitas di perairan tersebut.

Menurut Diharmi et al. (2011) garamgaram klorida yang tidak larut asam yang sebagian besar yaitu garam logam berat dan silika yang ditemukan di alam sebagai kuarsa, pasir dan batu yang biasa disebut dengan kadar abu tidak larut asam. Berdasarkan hasil dari analisis tersebut, kadar abu tidak larut asam pada karaginan adalah $0,03 \%$. Pada penelitan menunjukan bahwa kadar abu ini memenuhi standar mutu karaginan yang telah ditetapkan oleh FAO (2007).

Protein mampu menghasilkan berbagai produk dengan sifat-sifat yang lebih baik seperti peningkatan viskositas dan pembentukan gel, maka dari itu kareginan dapat berinteraksi dengan makromolekul lain yang bermuatan (Anggadiredja et al. 2007). Berdasarkan hasil dari analisis tersebut, kekuatan gel pada karaginan adalah $4,14 \mathrm{~g} / \mathrm{cm}^{2}$. Pada penelitan menunjukan bahwa kekuatan gel belum memenuhi standar mutu karaginan yang telah ditetapkan oleh FAO (2007).

Adapun faktor yang diduga mempengaruhi kekuatan gel tersebut yaitu tingginya kadar sulfat pada karaginan. waktu ekstraksi dapat mempengaruhi karaginan yang yang dihasilkan, semakin cepat waktu ekstraksi maka kandungan sulfatnya tinggi sehingga menyebabkan nilai kekuatan gel rendah (Faidliyah 2010;
Desiana

dan Hendrawati 2015).

Menurut Fajar dan aziz (2010) viskositas merupakan suatu hambatan air yang mengalir, jika nilai viskositas tinggi maka hambatan air tersebut semakin besar untuk mengalir. Berdasarkan hasil dari analisis tersebut, viskositas pada karaginan adalah 7,90 cP. Pada penelitan menunjukan bahwa viskositas ini memenuhi standar mutu karaginan yang telah ditetapkan oleh FAO (2007). Viskositas pada karaginan yang dihasilkan dari rumput laut memiliki kadar air tinggi lebih rendah dibandingkan dengan viskositas pada karaginan dengan rumput laut yang memiliki kadar air rendah (Harun et al. 2013).

Berdasarkan hasil analisis tersebut, titik leleh dan titik jendal pada karaginan tidak dapat diuji karena tidak membentuk gel pada proses analisis. $\mathrm{Hal}$ ini diduga karena banyak menghilangnya kadar sulfat, sehingga karaginan tersebut tidak membentuk gel. Hal ini sejalan dengan penelitian Suryaningrum (1988) yang menyatakan bahwa suhu titik jendal dan titik leleh berbanding terbalik dengan kandungan sulfat dan berbanding lurus dengan kandungan 3,6-anhidrogalaktosa.

\section{Teknologi Proses Pencampuran SRC dan RC}

Pada proses pencampuran (blending) terdapat perbedaan fisiko kimia pada karaginan yang sudah dicampurkan 
dengan konsentrasi yang berbeda-beda, ini dapat dilihat pada Tabel 2.

Berdasarkan hasil penelitian, kekuatan gel pada karaginan dengan konsentrasi tertentu menunjukan nilai sebesar 179,32-376,46 g/ $\mathrm{cm}^{2}$. Dengan penelitian ini dapat dilihat pada tabel 6 , bahwa nilai kekuatan gel yang tertinggi pada karaginan $\mathrm{D}$ dan terendah pada karaginan B. Pada penelitian ini dihasilkan karaginan yang tidak sesuai dengan standar mutu PES/EU 407A, tetapi pada karaginan ini tidak bisa dinyatakan bahwa karaginan tersebut tidak baik. Menurut FAO (2007) nilai kekuatan gel pada karaginan berkisar $20-500 \mathrm{~g} / \mathrm{cm}^{2}$, hal ini sejalan dengan penelitian Wenno et al. (2012) yaitu memiliki nilai 196,60-330,00 g/ $\mathrm{cm}^{2}$.

Menurut FAO (2007) nilai viskositas pada karaginan adalah minimal $5 \mathrm{cP}$. Viskositas memiliki faktor kualitas yang penting bagi zat cair dan semi cair (kental) atau produk murni, salah satunya adalah karaginan (Failu et al. 2016). Berdasarkan hasil penelitian didapatkan nilai berkisar 10,97 - 139,47
cP. Pada penelitian ini dengan konsentrasi yang berbeda, didapatkan nilai viskositas yang tertinggi pada karaginan $D$ dan terendah pada karaginan A. Dengan ini menunjukan bahwa karaginan pada penelitian sesuai dengan standar mutu PES/EU 407A.

Titik jendal adalah suhu larutan karaginan yang dalam konsentrasi tertentu mulai membentuk gel, sedangkan titik leleh merupakan kebalikannya yaitu suhu larutan karaginan yang mencair dengan konsentrasi tertentu (Wenno et al. 2012). Pada penelitian ini titik leleh memiliki nilai yang berkisar 55,70 $67,40{ }^{\circ} \mathrm{C}$, dengan ini dapat dilihat bahwa karaginan $\mathrm{C}$ memiliki nilai tertingi dan karaginan $\mathrm{D}$ memiliki nilai terendah. Sedangkan titik jendal memiliki nilai bekisar $38,00-44,10{ }^{\circ} \mathrm{C}$, dengan ini menunjukan nilai jendal tertinggi yaitu karaginan $\mathrm{B}$ dan nilai terendah adalah karaginan D. Menurut FAO (2007) menyatakan bahwa standar mutu PES/EU 407A masih belum diketahui.

Tabel 2. Fisiko Kimia Karaginan

\begin{tabular}{|c|c|c|c|c|c|}
\hline \multirow[b]{2}{*}{ Fisiko Kimia } & \multicolumn{5}{|c|}{ Karaginan } \\
\hline & A & B & $\mathbf{C}$ & D & $\begin{array}{l}\text { Standar Mutu } \\
\text { Karaginan }\end{array}$ \\
\hline $\begin{array}{l}\text { Kekuatan Gel } \\
\left(\mathrm{g} / \mathrm{cm}^{2}\right)\end{array}$ & 179,32 & 140,51 & 241,42 & 376,46 & $20-500^{a}$ \\
\hline Viskositas (cP) & 10,97 & 24,87 & 32,04 & 139,47 & $\operatorname{Min} .5^{\mathrm{a}}$ \\
\hline Titik Leleh $\left({ }^{\circ} \mathrm{C}\right)$ & 59,20 & 60,00 & 67,40 & 55,70 & - \\
\hline Titik Jendal $\left({ }^{\circ} \mathrm{C}\right)$ & 43,00 & 44,10 & 43,10 & 38,00 & - \\
\hline
\end{tabular}

Ket: $\mathrm{a}=$ FAO (2007) 


\section{KESIMPULAN}

Berdasarkan hasil penelitian ini pencampuran (blending) terbaik memiliki nilai karakteristik yang memenuhi standar karaginan yaitu karaginan $D$ dengan kekuatan gel $376,46 \mathrm{~g} / \mathrm{cm}^{2}$, viskositas 139,47 cP, titik leleh $55,70{ }^{0} \mathrm{C}$, dan titik jendal $38,00{ }^{\circ} \mathrm{C}$.

\section{DAFTAR PUSTAKA}

Anggadiredja TJ, Zatnika A, Purwoto H, Istini S. 2007. Rumput Laut. Jakarta : Penebar Swadaya.

Association of Official Analytical Chemist [AOAC]. 2005. Official of Analysis of the Association of Official Analytical of Chemist. Mayland (USA). The Association of Official Analytical of Chemist, Inc.

Badan Standarisasi Nasional. 2009. Rumput Laut Kering. SNI 2690.1:2009. Jakarta: Badan Standardisasi Nasional

Basmal J, Sedayu BB, Utomo BSB. 2009. Mutu Semi Refined Carrageenan (SRC) yang diproses menggunakan air limbah pengolahan src yang didaur ulang. Jurnal Pascapanen dan Bioteknologi Kelautan dan Perikanan. 4(1) : 1-11.

Chen K, Ríos JJ, Pérez-Gálvez A, Roca M. 2017. Comprehensive chlorophyll composition in the main edible seaweeds. Journal Food Chemistry. 228 (1): 625-633.

Diharmi A, Fardiaz D, Andarwulan N, dan Heruwati ES. 2011. Ekstraksi karagenan hasil isolasi (Eucheuma spinosum (Alga merah)) dari Perairan Semenep Madura. Jurnal Perikanan dan Kelautan. 16(1): 117-124

Desiana E, Hendrawati TY. 2015. Pembuatan karagenan dari Eucheuma cottonii dengan ekstraksi $\mathrm{KOH}$ menggunakan variabel waktu ekstraksi. Seminar Nasional Sains dan Teknologi. 1-7

Faidliyah NM. 2010. Tinjauan kualitas karaginan Eucheuma cottonii pada penggunaan pelarut dan waktu ekstraksi yang berbeda pada metode ekstraksi. Prosiding Seminar Nasional Teknik Kimia.

Failu I, Supriyono E, Suseno SH. 2016. Peningkatan kualitas karagenan rumput laut Kappaphycus alvarezii dengan metode budidaya keranjang jarring. Jurnal Akuakultur Indonesia. 15 (2): 124-131.

Fajar HR, Azis. A. 2010. Pemanfaatan abu kelopak batang pisang sebagai sumber alkali dalam ekstraksi karaginan dari rumput laut. Jurnal Media Perspektif. 10(1): 4-7.

Food Agricultural Organization. 2007. Compendium of Food Additive Spesificaton. Rome: Communication 
Division FAO Viale delle Terme di Caracalla.

Food Marine Colloids Corp. 1977. Carrageenan. Marine Monograph Number One. Marine Colloid Division FMC Corporation. Springfield,New Jersey.USA. p 23-29.

Freile-Pelegrin Y, Robledo D. 1997. Effects of season on the agar content and chemical characteteristics of Gracilaria cornea from Yucatan, Mexico. Journal Botanica Marina. 40(1): $285-290$

Harun M, Montolalu RI, Suwetja IK. 2013. Karateristik fisika kimia karaginan rumput laut jenis (Kappaphicus alvarezil) pada umur panen yang berbeda di Perairan Desa Tihengo Kabupaten Gorontalo Utara. Jurnal Media Teknologi Hasil Perikanan. 1(1): 7-12.

Hayashi L, de Paula EJ, Chow F. 2007. Growth rate and carrageenan analyses in four strains of Kappaphycus alvarezii (Rhodophyta, Gigartinales) farmed in the Subtropical Waters of São Paulo State, Brazil. Journal of Applied Phycology. 19(1): 393-399.

Hidayat, A., 2004. Pengaruh kelembaban udara terhadap kualitas rumput laut kering asin jenis Eucheuma cottonii dan Gracillaria sp Selama Penyimpanan. [Skripsi]. Departemen Teknologi Hasil Perikanan, Fakultas Perikanan dan
IImu Kelautan, Institut Pertanian Bogor, Bogor.

Ilhamdy, A.F., Jumsurizal., Shabilla, W.K, 2019. Sifat Fisiko-Kimia Semi Refined Carrageenan (SRC) Kappaphycus Alvarezii dari Perairan Karimun, Kepulauan Riau, Indonesia. Jurnal Perikanan dan Kelautan. 9(2):1-14

Keputusan Mentri Ketenagakerjaan Nomor 140 tahun 2016 tentang Penerapan Standar Kompetensi Kerja Nasional Indonesia Katagori Industri Pengolahan Golongan Pokok Industri Makanan Bidang Industri Pengolahan Rumput Laut Semi Refined Carrageenan dan Refined Carrageenan.

Kintanar QL, Lim-Sylianco CY, Gutierrez JR, Molina HA, Alba OM, Calderon, CJ, Pagsanhan EP, Balboa J, Serrame E, Guantes E, De Castro EG, Biares CIB, Calbitaza EL, Saitoh Y, Imai K. 1997. Toxicological Studies On Philippine Natural Grade Carrageenan. Scientific Paper: Toxicological Studies. 183-208.

McHugh, D. J. (2003). A guide to the seaweed industry: FAO fisheries technical paper No. 441 (pp. 61-72). Rome: FAO.

Siregar RF, Santoso J, Uju. 2016. Karakteristik fisiko kimia kappa karaginan hasil degradasi menggunakan hidrogen peroksida. Jurnal Pengolahan Hasil Perikanan Indonesia. 19(3): 256-266. 
Suryaningrum TD. 1988. Kajian sifatsifat mutu komoditi rumput laut budidaya jenis Eucheuma cottonii dan Eucheuma spinosum. [Tesis]. IPB. Bogor. Indonesia.

Sormin RBD, Soukotta D, Saiful, Risambessy, Ferdinandus ASSJ. 2018. Sifat fisiko-kimia Semi Refined Carrageenan dari Kota Ambon dan Kabupaten Maluku Tenggara Barat. Jurnal Pengolahan Hasil Perikanan Indonesia. 21(1): 92-98.

Wenno MR, Thenu JL, Lopulalan CGC. 2012. Karakteristik kappa karaginan dari Kappaphycus Alvarezi pada berbagai umur panen. Jurnal $P B$ Perikanan. 7(1): 61-67.

Yasita D, Rachmawati ID. 2009. Optimasi proses ekstraksi pada pembuatan karaginan dari rumput laut Eucheuma Cottoni untuk mencapai food grade. [Skripsi] Jurusan Teknik Kimia Fakultas Teknik Universitas Diponegoro

Yuniati, E. 2011. Karakteristik fisikokimia karagenan dan histologi rumput laut Kappaphycus alvarezii dari daerah asal bibit dan umur panen berbeda. [Tesis]. Sekolah Pascasarjana Institut Pertanian Bogor, Bogor. 